\title{
Controversy between John and Hugh Trevelyan.*
}

Yt maye please your L.shepp, Touchinge the staye of the Nisiprius betwene they two Trevelians, $\mathrm{yf}$ it had bine movid in the tyrme time, yet might have bine grauntted without offence to justice, but nowe after the terme I maye not grant any supersides to stay the same, unlese yt had procedid erroniuslie, and sethens I was justice I never grauntted any; and albeit I ame verye lothe to writ to staye procidinges in lawe, yet at your L.shepes motion I have writen a tre to the Justices of Assises ther, so as yt plese your L.shepes and my L. Keper writ also. The justices biginne not ther circut as I hier as yet this $\mathrm{xx}^{\text {th }}$ dayes; $\mathrm{yt}$ shalbe good the partie travell to them presently to knowe ther myndes therin, and returne ther aunswer to your L.shepe; and $y f$ they will not concent therunto, then I thinke no doubte but upon your L.shepes tres againe thei will procede, acordinge to your L.shepes last mosion in your tre, to have the principall gentellmen of the impannell to pase therin; and so take my leve of your good L.shepe. Cambbridge, this xxiijth of July, 1576 .

I send to your L.shepe the fre I writt to the Justices herin closed, to that end your L.shepe should perceve the contence therof.

Your L. moste bounden all waye at commandment, Christopher Wraye.

After my hartye commendacions to you bothe, $\mathrm{Her} \mathrm{Ma}^{\text {tie }}$ comitted a cause in contreversie betwene the tow Trevelians to my L. Keper and my L. Tresurer and myselfe; my L. Tresurer and I harde the same in Hyllerye terme in the absens of my L. Keper, and in the laste terme my L. Keper, my L. Tresurer and I hard the same

* The first of these three official letters (all cotemporary copies) was addressed by Sir C. Wray, Chief Justice of the Court of Queen's Bench, to Lord Burghley, with a copy of the second, "herein closed," to Justices Roger Manwood, puisné judge of the Common Pleas, and John Jeffries, puisné judge of the Queen's Bench ; and the third was written by Lord Burghley to the same two puisné judges. They probably relate to a suit at law, recorded in Plowden's Commentaries, regarding the estate brought into the family by Avice Cockworthy; for an abstract of which see Hodgson's History of Northumberland, Part 2, vol. i. p. 273 , note 9 b. 
agayne; and, havinge an intention finallye to ende the same, dyd finde some wante of confermite in Hughe Trevelian, and yet hopinge of his concent ther unto, did forbeare to sertifye her Matye of our procedinges therin, and so the mater restethe till the next terme, myndinge then ether finallye to ende it to ther contentations, or els make certificatt to her Highnes of our opinions in the same; but we all consideringe the wightines of the cause, the difycultnes did arise upon the hiringe therof, the tediousnes of the matter, and sundrye trialles had therin, some of one part, and some of another, thought it more fitte to be tried at Westminister then in the countrie, wher ye have small tym for so longe a mater: and declared our opinions to the parteis accordingly; wher upon John Trevelyan hathe foreborene to make anye provision for the same, as he seathe, and Hughe Trevelyan hath taken out an nysiprius, mindinge to trie it at the Assises; for which causes I, thinkinge ye shoulde doe verye well to move Hugh to staye, $y f$ he will not abydde our orders as we hoped he woulde, yet to staye his nisiprius, and take it triable in banke the next terme, who, havinge warninge therof, nowe takethe noe great deleay or hendrance therby. To this effecte, I thinke, my L. Treserer will writte to you also, and so bidd you hartylye farewell. Cambridge, this xxiiij ${ }^{\text {th }}$ of Julye, 1576.

Your lovinge Brother,

Christopher Wray. (L. Chief Justice of King's Bench.)

After most hartye commendacions, Wher ther is matter dependinge in contreversie betwext the two Trevelians, Hughe and John, which by her Majesties exprese order, bothe for the weightines and equitie of the cause, hath bine referred unto us two * and to the L. chyfe Justice to be in equitic heard and ended, wherin we two together with his L. have hade sondrie metinges and conferences, without such effect yet as we desired, and as we hoppe at some other metinge hereafter to bringe to passe; notwithstanding, findinge some deffi-

* The Lord Treasurer (Burghley) and the Lord Keeper (Bacon), as mentioned in the second letter. The latter was evidently expected to have joined in signing this letter, though he does not appear to have done so. 
culties which we laboured to ease and remove so well as we might, and partely letted by other busines, that we could not all have comoditye of metinge so as we wolde, beinge now geven to understand that Hughe Trevelian hathe sued out a nisiprius and intendethe to have a jurye to trye the causes depending betwext them in contreversie, and by hir $\mathrm{Ma}^{\text {tie }}$ for thei causes above specifeed referred unto us, and by us not remittid as yet, as nor intendid to be, for the desier we have by other meane then by processe of lawe to have it endid, and the good causes apearinge unto us that move us ther unto, we have thought good to signifie thus muche unto you by these our letters both of hir $\mathrm{Ma}^{\text {ts }}$ good pleasure touchinge these causes, and of our procedinge heretofor and intentions hereafter to proced accordinge therunto, when we shall all three mete againe, yf in the meane tym the trialls do not proced by nisiprius befor you, which we think good were forborne for thei causes abovesayde, and for that purpose doe writ these our letters unto you yf you wold in these respects do what you maie to staie such procedinge, lyke as we understande the L. Chiefe Justice hathe to the like effect written his letters also unto you: and hereof we praie you by this bearer to returne us your answers what you intende to doe, for that John Trevelyan, expectinge an end at our handes, is altogether unprovided of councell agenste the Asseses. And so we bied you hartely farewell. Frome the court, this $\mathrm{xxvj}^{\text {th }}$ of July, 1576.

(To)

Your very lovinge frindes,

Justice Manwood.
Justice GeffReYs.

W. BuRghLEY.

36 Eliz. A.D.

1593.

\section{Margery Trevelyan's Jointure**}

This Indenture, made the twentithe daye of October, in the sixe and thirteethe yeare of the Raigne of our Soveraigne Ladye Eliza-

* This counterpart is indorsed by Joln Trevelyan "The counterparte of my wyfes Joynter, Mrs. Margery Trevelyan." 